ISSN: 2528-4002 (Media Online)

ISSN: 2355-892x (Print)

Online: http://e-journal.sari-mutiara.ac.id/index.php/KesehatanMasyarakat

DOI: https://doi.org/10.51544/jkmlh.v6i2.2242

\title{
PENGARUH KOMUNIKASI KOERSIF TENTANG PROTOKOL KESEHATAN TERHADAP PENCEGAHAN PENULARAN VIRUS COVID-19 PADA IBU LANSIA DI ERA NEW NORMAL
}

\author{
Lely Febriani Nasution ${ }^{1}$, Etika Mulia Sari ${ }^{2}$ \\ ${ }^{12}$ Program Studi Kebidanan, Fakultas Kesehatan Universitas Audi Indonesia, Jalan \\ Bunga N'Cole Raya No.83, Medan Tuntungan, Indonesia \\ *Penulis Korespondensi: Lely Febriani Nasution, ${ }^{1}$ Program, \\ E-mail: nstfebri79@gmail.com,Phone:+6285263758854
}

\section{ABSTRAK}

Pada era pandemi saat ini, kelompok lansia merupakan kelompok yang paling berisiko mengalami keparahan/morbiditas dan mortalitas akibat penyakit Covid-19. Untuk itu pencegahan penularan melalui upaya promotif dan preventif terhadap Covid-19 bagi lansia menjadi prioritas, baik di tingkat masyarakat maupun di fasilitas kesehatan.

Upaya promotif dan preventif maka perlu dilakukan pendekatan dengan komunikasi koersif. Komunikasi koersif adalah proses penyampaian pesan (pikiran dan perasaan) oleh seseorang kepada orang lain untuk mengubah sikap, opini, atau perilaku dengan gaya yang mengandung paksaan sehingga memberikan dampak adanya kepatuhan akan kebijakan serta aturan dalam menjalankan protokol kesehatan seperti (menggunakan masker, mencuci tangan dan menjaga jarak) bahkan adanya sanksi bagi yang melanggar kebijakan dan aturan.

Jenis penelitian ini termasuk penelitian deskriptif dengan menggunakan metode penelitian lapangan (field research) dan penelitian kualitatif. Sampel penelitian ini yakni sebanyak 10 (sepuluh) lansia di Wilayah Kerja Puskesmas Patumbak. Sampel penelitian ditentukan secara non-random sampling dengan jenis purposive sampling dimana peneliti memilih sampel dari populasi menggunakan kriteria. Teknik pengumpulan data menggunakan metode observasi, dan wawancara. Data yang diperoleh kemudian dianalisis secara deskriptif dengan cara reduksi data, penyajian data dan penarikan kesimpulan.

Hasil penelitian diketahui bahwa petugas kesehatan menggunakan komunikasi koersif yang terdiri dari 5 tahapan yaitu menasihati, menegur, memberikan peringatan, memberikan hukuman, dan melakukan tindakan fisik kepada lansia. Komunikasi koersif memiliki efek terhadap lansia yaitu timbulnya rasa kekhawatiran, rasa takut akan penting protokol kesehatan guna memutus penyebaran virus Covid-19. Saran peneliti terhadap petugas kesehatan yang membaca, atau pembaca yang akan menjadi petugas kesehatan agar tidak terlalu keras atau kasar terhadap lansia sehingga dapat memberikan efek jera, namun jangan sampai dan sebisa mungkin dihindari untuk melakukan tindakan fisik ke lansia agar lansia tidak mengalami trauma akan rasa takut yang berlebih akan adanya aturan dan kebijakan protol kesehatan.

Kata kunci: Komunikasi Koersif, Protokol Kesehatan, Pencegahan, Penularan Covid-19, Lansia.

\section{PENDAHULUAN}

Pandemi Covid-19 telah Dampak tersebut berpengaruh signifikan memberikan tekanan dan dampak yang besar pada dunia, termasuk indonesia. baik di bidang kesehatan maupun non-kesehatan. Pandemi Covid-19 di 
ISSN: 2528-4002 (Media Online)

ISSN: 2355-892x (Print)

Online: http://e-journal.sari-mutiara.ac.id/index.php/KesehatanMasyarakat

DOI: https://doi.org/10.51544/jkmlh.v6i2.2242

Indonesia memberikan pembelajaran berharga, bahwa Indonesia harus terus berbenah dalam berbagai bidang pembangunan disegala sektor. Salah satu hal yang sangat krusial yang membutuhkan percepatan penanganan dibidang kesehatan. Salah satu dampak Covid-19 adanya ancaman penyakit yang terjadi pada semua kelompok umur, terutama pada kelompok umur tua atau lanjut usia. Kelompok lanjut usia memiliki risiko yang signifikan terkena penyakit virus corona ini, apalagi jika mereka mengalami gangguan kesehatan seiring dengan penurunan kondisi secara fisiologi.

Mengacu pada data WHO, lebih dari 95\% kematian akibat Virus Corona terjadi pada penduduk usia lebih dari 60 tahun. Lebih dari $50 \%$ dari semua kematian melibatkan terjadi pada mereka yang berusia 80 tahun atau lebih. Dari laporan WHO dapat dilihat bahwa 8 dari 10 kematian terjadi pada individu dengan setidaknya satu komorbiditas, khususnya mereka dengan penyakit kardiovaskular, hipertensi dan diabetes, tetapi juga dengan berbagai kondisi kronis lainnya. ${ }^{2}$

Badan Organisasi Dunia (WHO) menetapkan berbagai standar kesehatan guna melindungi dan penyelamatan diri dari virus berbahaya ini. Selain itu tak ketinggalan juga WHO mengingatkan agar semua masyarakat memastikan lanjut usia mendapatkan apa yang mereka butuhkan. Sangat penting bagi negara untuk memberikan respon komprehensif terhadap pandemi ini, dengan mendukung lanjut usia, keluarga dan pengasuhnya. Pada kondisi pandemi seperti ini, lanjut usia memerlukan perlindungan, dan akses terhadap makanan bergizi, ketersediaan kebutuhan dasar, uang, obat-obatan untuk mendukung kesehatan fisik, dan perawatan sosialnya. Selain itu, lanjut usia memerlukan akses terhadap informasi yang akurat, terutama terkait menjaga kesehatan fisik dan mental selama pandemik. Informasi ini juga terkait dengan langkah-langkah yang harus dilakukan jika mereka sakit. ${ }^{2}$

Indonesia merupakan negara dengan struktur penduduk tua (Aging Population), dimana populasi lanjut usia (lansia) saat ini diproyeksikan sebesar 27,08 juta jiwa atau $9,99 \%$ dari total penduduk Indonesia. Permasalahan kesehatan pada populasi lansia antara lain sebanyak $63.5 \%$ lansia menderita Hipertensi, 5.7\% lansia dengan Diabetes Mellitus, $4.5 \%$ lansia dengan Penyakit Jantung, 4.4\% lansia dengan Stroke, $0.8 \%$ lansia dengan Gangguan Ginjal dan $0.4 \%$ lansia menderita Kanker. ${ }^{3}$

Data mortalitas di Indonesia menunjukkan dimana angka mortalitasnya meningkat seiring dengan meningkatnya usia yaitu pada populasi usia 45-54 tahun adalah 8\%, 55-64 tahun sebanyak $14 \%$ dan 65 tahun ke atas $22 \%$. Untuk itu pencegahan penularan melalui upaya promotif dan preventif kepada kelompok lansia sangat penting dilakukan, baik di tingkat keluarga, masyarakat dan fasilitas Kesehatan. Namun upaya promotif dan preventif tidak dapat menekan penurunan penyebaran virus covid-19 pada kelompok lansia di era new normal.

Lansia sebagai kelompok rentan tentu saja sangat membutuhkan dukungan dari keluarga dan masyarakat agar kesehatan dan kualitas hidup lansia selama masa pandemi Covid-19 dapat tetap terjaga seoptimal mungkin. Untuk itu perlu disusun suatu pedoman yang menjadi acuan bagi tenaga kesehatan dalam melakukan pelayanan kesehatan bagi lansia pada era pandemi Covid-19, dengan 
ISSN: 2528-4002 (Media Online)

ISSN: 2355-892x (Print)

Online: http://e-journal.sari-mutiara.ac.id/index.php/KesehatanMasyarakat

DOI: $\underline{\text { https://doi.org/10.51544/jkmlh.v6i2.2242 }}$

prioritas pada layanan promotif dan preventif. $^{4}$

Berdasarkan data gugus pengendalian virus corona dilihat pada tanggal 23 April 2020, Indonesia Dari 6714 orang yang terkonfirmasi positif, laki-laki $(59,1 \%)$ dibanding perempuan $(40,9 \%)$. Urutan sesuai usia, sebagai berikut yaitu 18-65 tahun (5.757), 65 tahun ke atas (731 orang), 5-17 tahun (175 orang), dan 0-4 tahun (51 orang). Sedangkan data pada Provinsi Sumatera Utara didapat data bahwa jumlah orang dianggap penderita (ODP) saat ini sudah mencapai 3.080 orang. Terjadi peningkatan dari sehari sebelumnya sebesar 35,8 persen, yakni 1.976 orang. Untuk sebaran ODP, saat ini terbesar di Kabupaten Deli Serdang disusul Kota Medan. Dari data sebaran ODP di dapat bahwa mayoritas termasuk kelompok lansia. ${ }^{7}$

Data seberan tersebut juga menjelaskan bahwa puskesmas patumbak berada di Kabupaten Deli Serdang. Hasil wawancara peneliti terhadap salah satu staf puskesmas patumbak di dapat informasi mengenai data sebaran dari gugus penanggulan virus corona, bahwa

\section{METODE}

Jenis penelitian ini termasuk penelitian deskriptif yang berkaitan dengan situasi yang memerlukan teknik pengumpulan data dan informasi melalui wawancara dan melakukan observasi (pengamatan) secara langsung dengan menggunakan metode penelitian lapangan (field research) dan penelitian kualitatif. Data yang dibutuhkan dalam penelitian ini adalah data yang berkenaan dengan pengaruh komunikasi koersif tentang Protokol Kesehatan Terhadap Pencegahan Penularan Virus Covid-19 Pada Ibu Lansia di Era New Normal. Populasi dalam penelitian ini adalah seberan tersebut meningkat dikarenakan banyak masyarakat termasuk lansia yang belum patuh akan protokol kesehatan seperti menggunakan masker, mencuci tangan dan menjaga jarak. Hasil observasi yang dilakukan peneliti pada tanggal 22 September Tahun 2020 ditemukan peneliti bahwa ada 5 (lima) lansia yang datang ke puskesmas patumbak tidak menggunakan aturan protokol kesehatan seperti menggunakan masker. Peneliti juga melakukan wawancara kepada 2 (dua) lansia mengenai aturan perotol kesehatan, dari hasil wawancara didapatkan informasi bahwa lansia mengatakan tidak percaya akan adanya virus corona dan menganggap bahwa virus corona sebagai strategi politik. Selain itu, didapat informasi bahwa lansia tidak merasa nyaman menggunakan masker sebagai aturan protokol kesehatan.

Berdasarkan latar belakang diatas, perlu dikaji Pengaruh Komunikasi Koersif tentang Protokol Kesehatan Terhadap Pencegahan Penularan Virus Covid-19 Pada Ibu Lansia di Era New Normal.

seluruh lansia yang berada di wilayah kerja Puskesmas Patumbak Kecamatan Patumbak. Populasi penelitian ini akan diambil berdasarkan data dari Puskesmas Patumbak sebanyak 67 lansia. Sampel adalah sebagian dari jumlah dan karakteristik yang dimiliki oleh populasi. Sampel yang digunakan dalam penelitian ini adalah teknik "non random sampling" yaitu cara pengambilan sampel yang tidak semua anggota populasi diberi kesempatan untuk dipilih menjadi sampel, yang memenuhi kriteria sebagai sampel yakni sebanyak 10 (sepuluh) lansia. 
ISSN: 2528-4002 (Media Online)

ISSN: 2355-892x (Print)

Online: http://e-journal.sari-mutiara.ac.id/index.php/KesehatanMasyarakat

DOI: https://doi.org/10.51544/jkmlh.v6i2.2242

HASIL

A. Perilaku lansia di puskesmas patumbak

Menurut Permensos Nomor 5

Tahun 2018 bahwa lanjut usia merupakan seseorang yang telah mencapai enam puluh tahu keatas. Lanjut usia (lansia) merupakan perjalanan hidup saat manusia memasuki tahapan akhir dari fase kehidupannya. Lansia kerap juga disebut the beginning of the end.

Pandemi Covid-19 merupakan badai yang menimpa manusia. Beberapa foto yang beredar memperlihatkan situasi pandemik, semua orang menggunakan masker, larangan mengadakan pertemuan di tempat umum bahkan di masjid, gereja dan tempat ibadah lain, serta pesan seperti, "wearing mask or go to jail".

B. Aturan dan Kebijakan protokol kesehatan puskesmas patumbak

Lansia merupakan suatu

kelompok penduduk yang cukup rentan dan terdampak dalam masalah kesehatan dan psikologis di era pandemi COVID 19 (new normal). Aturan dan kebijakan yang diberikan puskesmas patumbak adalah dengan melakukan 3M (Menjaga jarak, Mencuci Tangan, dan Memakai Masker) agar menjaga lansia dari paparan pada saat berkunjung ke posyandu lansia.

\section{Aturan dan Kebijakan 3M Pada Lansia}

Pelayanan kesehatan pada lansia di fasilitas kesehatan dilakukan sesuai Standar Operasional Prosedur (SOP) pelayanan yang berlaku dengan pengaturan serta modifikasi melalui $3 \mathrm{M}$ untuk mencegah penularan Virus Covid-19 bagi tenaga kesehatan maupun pasien pengunjung fasilitas kesehatan termasuk para lansia.

Pengunjung Puskesmas yang datang terutama pasien lansia dapat menyampaikan pesan pesan antara lain : a) sejak dari rumah pakai masker; b) menjaga jarak fisik; c) etika batuk \& bersin; d) meminimalkan yang berkunjung ke Puskesmas; e) memperhatikan jadwal pelayanan khusus lansia dan jam kehadiran; f) bagi pasien lansia dianjurkan untuk menunda datang ke fasilitas kesehatan kecuali mengalami kondisi kegawat daruratan.

Dengan komunikasi yang baik tersebut, maka dapat terjadilah hubungan timbal balik antara petugas kesehatan dan lansia atau sebaliknya. Hubungan timbal balik ini sangat diperlukan dalam menjaga kerukunan antara petugas kesehatan dan lansia. Petugas kesehatan juga sangat berperan penting dalam penerimaan informasi kepada lansia.

Petugas kesehatan yang berkomunikasi dengan lansia juga terlihat buru-buru terkadang memberikan informasi hanya sekedar membaca pengumumman/banner kepada lansia, sehingga tak jarang lansia tersebut menganggap bahwa informasi tidak penting hal hasil lansia banyak yang mendapat teguran atau komunikasi koersif pada saat berkunjung ulang ke Puskesmas.

1) Data Lansia Di Puskesmas Patumbak

Adapun data lanjut usia yang berada di Puskesmas Patumbak sebagai berikut :

a) Lansia Doni

Bapak Doni yang memiliki nama lengkap Doni Iskandar, berusia 67 tahun saat saat ini keseharian dirumah dengan melakukan kegiatan aktifitas ringan. Pendidikan terakhir Bapak Doni adalah Sekolah Menengah Pertama (SMP). Bapak doni memiliki 4 (empat) orang anak yang sudah menikah. Bapak Doni tinggal sendiri 
Online: http://e-journal.sari-mutiara.ac.id/index.php/KesehatanMasyarakat

DOI: https://doi.org/10.51544/jkmlh.v6i2.2242

dirumah namun disamping rumah bapak doni dari anak nya paling kecil bernama maya. Bapak Doni mengaku selalu ditegur oleh pihak petugas puskesmas karena tidak menggunakan masker dengan benar dan lupa melakukan cuci tangan. Bapak doni mengatakan dengan adanya teguran tersebut membuat bapak doni lebih batuh melaksanakan $3 \mathrm{M}$ dengan benar.

"Walaupun saya nggak tentu kapan pergi puskesmas yang jelas disaat say tidak enak badan maka saya segera ke puskesmas, asal saya ketemu petugas kesehatan dipuskesmas terutama satpam saya pasti ditegur agar memakai masker dengan benar dengan menutup sampai hidung. Saya terimah saja kalau saya ditegur apalagi terkait 3M agar saya tidak terpapar corona, mbak. Tapi kalau saya sudah ditegur, maka saya tidak akan lupa menggunakan masker dengan benar jika saya berkunjung ke puskesmas atas ke posyandu lansia, saya percaya teguran tersebut untuk mengingatkan saya."

Dalam menerima informasi aturan 3M, Bapak doni mendapatkan komunikasi koersif dari petugas dengan menegur bapak doni karena tidak menggunakan masker, namun Bapak Doni paham aturan 3M karena petugas juga memberikan penjelasan aturan penggunaan maker yang benar.

b) Lansia Sumarti

Ibu Sumarti berusia 63 tahun dan bekerja sebagai pemilik toko keripik bernama "Alinda". Suaminya bernama Bapak
Sutrisno dan bekerja sebagai pemilik toko keripik juga. Pendidikan terakhir Ibu Sumarti adalah Sekolah Menengah Atas (SMA). Pasangan ini memiliki anak sebanyak tiga (3). Ibu Sumarti merupakan orang yang sibuk setiap hari sehingga membuat ibu sumiarti mudah lelah. Setiap ibu sumiarti kelelahan maka ibu sumiarti selalu cek up ke puskesmas. Ketika ibu sumiarti ke puskesmas beliau selalu sering lupa mengunakan masker, karena ibu sumiarti tidak suka pakai masker, oleh karena itu saya selalu ditegur oleh petugas bahkan setiap cek up saya tidak diterima masuk yang merupakan sanksi akan aturan puskesmas pada masa pandemi. Namun, Ibu Sumarti mengaku dapat menerima aturan tersebut karena itu kebaikkan untuk semua orang.

"Walaupun sibuk saya tetap perioritaskan kesehatan. Oleh karena itu, jika saya sudah lelah saya selalu ke puskesmas namun kebiasaan saya adalah lupa. Saya selalu lupa menggunakan masker bahkan setiap puskesmas saya sering balik lagi kerumah untuk mengambil masker. Karena situasi corona ini membuat saya juga kadang khawatir kalau ke puskesmas tidak menggunakan masker. Pernah saya ke puskesmas lupa tidak pakai masker saya sama sekali tidak ditangani karena tidak menggunakan masker karena petugasnya takut kalau saya nanti terpapar corona.".

Dalam menerima informasi 
Online: http://e-journal.sari-mutiara.ac.id/index.php/KesehatanMasyarakat

DOI: https://doi.org/10.51544/jkmlh.v6i2.2242

aturan 3M, Ibu Sumiarti mendapatkan komunikasi koersif dari petugas dengan tidak melayani karena tidak patuh aturan $3 \mathrm{M}$ yang telah ditetapkan oleh puskesmas patumbak.

c) Lansia Tati Suranti

Ibu Tati Suranti berusia 63 tahun adalah pensiunan guru. Pendidikan terakhir Ibu Tati Suranti adalah Sarjana (S1). Ibu Tati Suranti memiliki penyakit hipertensi sehingga membuat ibu tati sering melakukan chek-up kesehatan ke puskesmas sehingga dimasa pandemi ini juga, Ibu Tati Suranti juga selalu datang ke puskesmas atau posyandu untuk melakukan pemeriksaan kesehatannya.

"Saya mempunyai penyakit hipertensi, jadi ketika penyakit saya kambuh, saya segera diantarkan anak saya berobat ke puskesmas. Namun, yang nama saya sakit terkadang saya tidak sadar lagi karena menahan sakit untuk menggunakan dan melaksanakan $3 \mathrm{M}$ yaitu menggunakan masker. Oleh karena itu, saya sering ditegur petugas kesehatan. Tapi alhamdulillahnya, saya menerima teguran karena disampaikan dengan baik dan lembut. Teguran yang disampaikan juga memberikan peringatan agar saya selalu memperhatikan kesehatan dan penecegahan agar saya tidak terpapar virus corona.

Dalam melakukan chec-up, Ibu Tati Suranti mendapatkan komunikasi koersif dari petugas kesehatan dengan teguran untuk tidak mengulang lagi untuk tidak menggunakan masker. d) Lansia Nur

Ibu Nur berusia berusia 63 tahun, yang setiap hari berdagang di pasar. Suaminya, Bapak Ramon yang berusia 69 tahun merupakan seorang supir truk. Pendidikan terakhir Ibu Nur dan Bapak Ramon adalah Sekolah Menengah Atas (SMA). Ibu Nur memiliki riwayat sesak nafas yang membuat ibu nur tidak suka menggunakan masker sehingga disaat ibu nur berkunjungan ke puskesmas ibu nur tidak menggunakan masker.

"Saya memiliki riwayat sesak nafas yang membuat saya tidak suka menggunakan masker kemana pun saya pergi, namun karena saya pergi ke puskesmas, saya terpaksana menggunakan masker ketika sampai di puskesamas. Karena sebelumnya saya pernah tidak dilayanai petugas disaat saat membantah petugas agar saya menggunakan masker, saya membantah karena saya punya penyakit sesak. Namun, ketika petugas tersebut memberikan penjelasan serta membuat saya jera tidak dilayani oleh petugas, oleh karena itu saya tetap menggunakan masker ketika saya berada diruangan ramai".

Dalam keadaan sakit, Ibu Nur merasa berterima kasih karena sudah diberikan penjelasan serta sanksi tidak dilayani oleh petugas jika saya tidak menggunakan masker. Bentuk komunikasi koersif memberikan efek jera sehingga lansia bias patuh.

e) Lansia Ida

Ibu Ida berusia berusia 63 tahun, yang setiap hari berdagang 
Online: http://e-journal.sari-mutiara.ac.id/index.php/KesehatanMasyarakat

DOI: https://doi.org/10.51544/jkmlh.v6i2.2242

di pasar. Suaminya, Bapak

Ramon yang berusia 69 tahun merupakan seorang supir truk. Pendidikan terakhir Ibu Ida dan Bapak Kokoh adalah Sekolah Menengah Atas (SMA). Ibu Nur memiliki riwayat sesak nafas yang membuat ibu nur tidak suka menggunakan masker sehingga disaat ibu nur berkunjungan ke puskesmas ibu ida tidak menggunakan masker.

"Saya memiliki riwayat sesak nafas yang membuat saya tidak suka menggunakan masker kemana pun saya pergi, namun karena saya pergi ke puskesmas, saya terpaksana menggunakan masker ketika sampai di puskesamas. Karena sebelumnya saya pernah tidak dilayanai petugas disaat saat membantah petugas agar saya menggunakan masker, saya membantah karena saya punya penyakit sesak. Namun, ketika petugas tersebut memberikan penjelasan serta membuat saya jera tidak dilayani oleh petugas, oleh karena itu saya tetap menggunakan masker ketika saya berada diruangan ramai".

Dalam keadaan sakit, Ibu ida merasa berterima kasih karena sudah diberikan penjelasan serta sanksi tidak dilayani oleh petugas jika saya tidak menggunakan masker. Bentuk komunikasi koersif memberikan efek jera sehingga lansia bias patuh.

f) Lansia Ria

Ibu Ria berusia 63 tahun adalah pensiunan guru. Pendidikan terakhir Ibu Ria adalah Sarjana (S1). Ibu Ria memiliki penyakit hipertensi sehingga membuat ibu ria sering melakukan chek-up kesehatan ke puskesmas sehingga dimasa pandemi ini juga, ibu ria juga selalu datang ke puskesmas atau posyandu untuk melakukan pemeriksaan kesehatannya.

"Saya mempunyai penyakit hipertensi, jadi ketika penyakit saya kambuh, saya segera diantarkan anak saya berobat ke puskesmas. Namun, yang nama saya sakit terkadang saya tidak sadar lagi karena menahan sakit untuk menggunakan dan melaksanakan 3M yaitu menggunakan masker. Oleh karena itu, saya sering ditegur petugas kesehatan. Tapi alhamdulillahnya, saya menerima teguran karena disampaikan dengan baik dan lembut. Teguran yang disampaikan juga memberikan peringatan agar saya selalu memperhatikan kesehatan dan penecegahan agar saya tidak terpapar virus corona.

Dalam melakukan chec-up, ibu ria mendapatkan komunikasi koersif dari petugas kesehatan dengan teguran untuk tidak mengulang lagi untuk tidak menggunakan masker.

g) Lansia Rina

Ibu Rina berusia 63 tahun dan bekerja sebagai pemilik toko keripik bernama "Alinda". Suaminya bernama Bapak Triyono dan bekerja sebagai pemilik toko keripik juga. Pendidikan terakhir Ibu Rina adalah Sekolah Menengah Atas (SMA). Pasangan ini memiliki anak sebanyak tiga (3). Ibu Rina merupakan orang yang sibuk setiap hari sehingga membuat 
ISSN: 2355-892x (Print)

Online: http://e-journal.sari-mutiara.ac.id/index.php/KesehatanMasyarakat

DOI: https://doi.org/10.51544/jkmlh.v6i2.2242

ibu sumiarti mudah lelah. Setiap

Ibu Rina kelelahan maka ibu sumiarti selalu cek up ke puskesmas. Ketika Ibu Rina ke puskesmas beliau selalu sering lupa mengunakan masker, karena Ibu Rina tidak suka pakai masker, oleh karena itu saya selalu ditegur oleh petugas bahkan setiap cek up saya tidak diterima masuk yang merupakan sanksi akan aturan puskesmas pada masa pandemi. Namun, Ibu Rina mengaku dapat menerima aturan tersebut karena itu kebaikkan untuk semua orang.

"Walaupun sibuk saya tetap perioritaskan kesehatan. Oleh karena itu, jika saya sudah lelah saya selalu ke puskesmas namun kebiasaan saya adalah lupa. Saya selalu lupa menggunakan masker bahkan setiap puskesmas saya sering balik lagi kerumah untuk mengambil masker. Karena situasi corona ini membuat saya juga kadang khawatir kalau ke puskesmas tidak menggunakan masker. Pernah saya ke puskesmas lupa tidak pakai masker saya sama sekali tidak ditangani karena tidak menggunakan masker karena petugasnya takut kalau saya nanti terpapar corona."

Dalam menerima informasi aturan 3M, Ibu Sumiarti mendapatkan komunikasi koersif dari petugas dengan tidak melayani karena tidak patuh aturan $3 \mathrm{M}$ yang telah ditetapkan oleh puskesmas patumbak.

h) Lansia Rum

Ibu Nur berusia berusia 60 tahun, yang setiap hari berdagang di pasar. Suaminya, Bapak Rafi yang berusia 60 tahun merupakan seorang supir truk. Pendidikan terakhir Ibu Rum dan Bapak Rafi adalah Sekolah Menengah Atas (SMA). Ibu Rum memiliki riwayat sesak nafas yang membuat ibu rum tidak suka menggunakan masker sehingga disaat ibu rum berkunjungan ke puskesmas ibu rum tidak menggunakan masker.

"Saya memiliki riwayat sesak nafas yang membuat saya tidak suka menggunakan masker kemana pun saya pergi, namun karena saya pergi ke puskesmas, saya terpaksana menggunakan masker ketika sampai di puskesamas. Karena sebelumnya saya pernah tidak dilayanai petugas disaat saat membantah petugas agar saya menggunakan masker, saya membantah karena saya punya penyakit sesak. Namun, ketika petugas tersebut memberikan penjelasan serta membuat saya jera tidak dilayani oleh petugas, oleh karena itu saya tetap menggunakan masker ketika saya berada diruangan ramai".

Dalam keadaan sakit, Ibu rum merasa berterima kasih karena sudah diberikan penjelasan serta sanksi tidak dilayani oleh petugas jika saya tidak menggunakan masker. Bentuk komunikasi koersif memberikan efek jera sehingga lansia bias patuh.

i) Lansia Ros

Ibu Ros berusia berusia 60 tahun, yang setiap hari berdagang di pasar. Pendidikan terakhir Ibu Ros berpendidikan Sekolah Menengah Atas (SMA). Ibu Ros memiliki riwayat sesak nafas yang membuat ibu rum tidak suka menggunakan masker 
ISSN: 2528-4002 (Media Online)

ISSN: 2355-892x (Print)

Online: http://e-journal.sari-mutiara.ac.id/index.php/KesehatanMasyarakat

DOI: https://doi.org/10.51544/jkmlh.v6i2.2242

sehingga disaat ibu rum berkunjungan ke puskesmas ibu rum tidak menggunakan masker.

"Saya memiliki riwayat TBC yang membuat saya tidak suka menggunakan masker kemana pun saya pergi, namun karena saya pergi ke puskesmas, saya terpaksana menggunakan masker ketika sampai di puskesamas. Karena sebelumnya saya pernah tidak dilayanai petugas disaat saat membantah petugas agar saya menggunakan masker, saya membantah karena saya punya

\section{PEMBAHASAN}

Hasil penelitian ini akan membahas tentang analisis data yang diperoleh dari hasil penelitian yang telah penulis lakukan. Setelah penulis melakukukan observasi dan wawancara. Maka penulis akan menganalisis hasil penelitian dengan pokok masalah bagaimana Pengaruh Komunikasi Koersif tentang Protokol Kesehatan Terhadap Pencegahan Penularan Virus Covid-19 Pada Ibu Lansia di Era New Normal.

Segala bentuk komunikasi mempunyai efek dan tujuannya masing-masing terhadap komunikan atau orang yang menerima atau mendengarkan pesan yang disampaikan oleh komunikator. Di sini, petugas kesehatan sebagai komunikator memberikan pesan kepada lansia sebagai komunikan dengan tujuan kognitif atau memberikan informasi, pengetahuan, dan menambah wawasan kepada anak, tujuan afektif yaitu menyampaikan pikiran, ide, perasaan kepada anak, dan juga dengan tujuan konatif atau psikomotorik yaitu mengubah sikap, perilaku, dan perbuatan lansia. penyakit sesak. Namun, ketika petugas tersebut memberikan penjelasan serta membuat saya jera tidak dilayani oleh petugas, oleh karena itu saya tetap menggunakan masker ketika saya berada diruangan ramai”.

Dalam keadaan sakit, Ibu Ros merasa berterima kasih karena sudah diberikan penjelasan serta sanksi tidak dilayani oleh petugas jika saya tidak menggunakan masker. Bentuk komunikasi koersif memberikan efek jera sehingga lansia bias patuh

\section{KESIMPULAN}

Berdasarkan hasil penelitian yang telah dilakukan oleh penulis tentang Pengaruh Komunikasi Koersif tentang Protokol Kesehatan Terhadap Pencegahan Penularan Virus Covid-19 Pada Ibu Lansia di Era New Normal, maka hasil penelitian dan pembahasan yang telah dibahas pada bab sebelumnya, mendapatkan bahwa penerapan komunikasi koersif petugas kesehatan memiliki 5 (lima) tahapan dan juga memiliki efek jera terhadap kepada lansia. Tahapan dalam komunikasi koersif petugas kesehatan diantaranya yaitu yang pertama petugas kesehatan menasihati lansia, lalu petugas kesehatan menegur lansia, yang ketiga petugas kesehatan akan memberikan peringatan kepada lansia, selanjutnya petugas kesehatan akan memberi hukuman kepada lansia, dan yang terakhir petugas kesehatan akan melakukan tindakan fisik kepada lansia. Efek komunikasi koersif memberikan efek jera kepada lansia yaitu terjadinya kekhawatiran, rasa takut akan penting protokol kesehatan guna memutus penyebaran virus covid-19. 
ISSN: 2528-4002 (Media Online)

ISSN: 2355-892x (Print)

Online: http://e-journal.sari-mutiara.ac.id/index.php/KesehatanMasyarakat

DOI: https://doi.org/10.51544/jkmlh.v6i2.2242

UCAPAN TERIMAKASIH

Saya berterima kasih kepada semua pihak yang turut membantu dalam penyelesaian Penelitian ini, baik dukungan moril, motivasi, materi dan masukan - masukan yang diberikan kepada saya sehingga penelitian ini dapat terselesaikan dengan baik.

\section{REFERENSI}

Nidya, Sari. 2020. Statistik Penduduk Lanjut Usia. Jakarta : Badan Pusat Statistik

Muctar, dll., 2020. Perlindungan Sosial Lanjut Usia Masa Pandemi Covid-19. Jakarta : Pusat Penelitian dan Pengembangan Kesejahteraan Sosial.

Budi, Harsana, dll., 2021. Studi Pembelajaran Penanganan Covid-19 Indonesia. Jakarta : BAPENNAS.

Effendy, Onong Uchjana. Ilmu Komunikasi Teori dan Praktek. Bandung: Remaja Rosdakarya. 2005.

Liliweri, Alo. Komunikasi Serba Ada Serba Makna. Jakarta: Kencana. 2011.

Cangara, Hafied. 2018. Pengantar Ilmu Komunikasi. Jakarta: Rajagrafindo Persada.

Suprapto, Tommy. Pengantar Teori dan Manajemen Komunikasi Yogyakarta: Media Pressindo. 2019.
Uripni, Christina Lia, Untung Sujianto, Tatik Indrawati. Komunikasi Kebidanan. Jakarta: Kedokteran EGC. 2003.

Chaplin, J.P., 2016. Kamus Lengkap Psikologi. Jakarta: Raja Grafindo.

Chairunnisa., 2019. Jouernal Komunikasi Koersif Orangtua Terhadap Perkembangan Mental Spiritual Anak Di Kelurahan Gunung Agung Kecamatan Langkapura Bandar Lampung. 22 Januari 2019.

Gugus Tugas Percepatan Penanganan Covid-19, April 2020. Rekomendasi Standar Penggunaan APD untuk Penanganan Covid-19 di Indonesia Revisi 1. Jakarta.

CDC, 2019. Infection Prevention and Control Assesment and Response Tool (ICAR), https://www.cdc.gov/coronavirus/201 9ncov/hcp/assessment-tool-for-nursin g homes.html

Arikunto, Suharsimi. Prosedur Penelitian: Suatu Pendekatan Praktek. Jakarta: Rineka Cipta.1985.

Rakhmat, Jalaluddin. Metode Penelitian Komunikasi. Bandung: Remaja Rosdakarya. 2007. 